\title{
Transactions
}

Cite this: Dalton Trans., 2012, 41, 8512

wWw.rsc.org/dalton

COMMUNICATION

\section{Polytypism and oxo-tungstate polyhedra polymerization in novel complex uranyl tungstates $\uparrow$}

\author{
Andrey N. Seliverstov, ${ }^{a, b}$ Evgeny V. Suleimanov, ${ }^{a}$ Evgeny V. Chuprunov, ${ }^{a}$ Nikolay V. Somov, ${ }^{a}$ \\ Elena M. Zhuchkova, ${ }^{a}$ Maxim I. Lelet, ${ }^{a}$ Konstantin B. Rozov, ${ }^{c}$ Wulf Depmeier, ${ }^{d}$ Sergey V. Krivovichev ${ }^{e}$ \\ and Evgeny V. Alekseev*c,f
}

\author{
Received 8th May 2012, Accepted 4th June 2012 \\ DOI: $10.1039 / \mathrm{c} 2 \mathrm{dt31000g}$
}

Three new uranyl tungstates, $\alpha$-, $\beta-\mathrm{Cs}_{2}\left[\left(\mathrm{UO}_{2}\right)_{2}\left(\mathrm{~W}_{2} \mathrm{O}_{9}\right)\right]$, and $\mathrm{Rb}_{6}\left[\left(\mathrm{UO}_{2}\right)_{7}\left(\mathrm{WO}_{5}\right)_{2}\left(\mathrm{~W}_{3} \mathrm{O}_{13}\right) \mathrm{O}_{2}\right]$, have been obtained by high temperature solid state reactions. All three compounds display novel structure topologies: $\alpha$ - and $\beta-\mathrm{Cs}_{2}\left[\left(\mathrm{UO}_{2}\right)_{2}\right.$ $\left.\left(\mathrm{W}_{2} \mathrm{O}_{9}\right)\right]$ are based upon layers with a new topology that can be related to the uranophane topology; $\mathrm{Rb}_{6}\left[\left(\mathrm{UO}_{2}\right)_{7}\left(\mathrm{WO}_{5}\right)_{2}\right.$ $\left(\mathrm{W}_{3} \mathrm{O}_{13}\right) \mathrm{O}_{2}$ ] is a rare example of a non-molecular inorganic phase with layers containing oxo-tungstate trimers. The structural relationship between $\alpha$ - and $\beta-\mathrm{Cs}_{2}\left[\left(\mathrm{UO}_{2}\right)_{2}\left(\mathrm{~W}_{2} \mathrm{O}_{9}\right)\right]$ can be assigned to polytypism.

The chemistry of actinides is an important and currently active field of inorganic chemistry. Actinides and their compounds play a prime role in nuclear waste management and safety assessment. ${ }^{1-3}$ In particular, investigations of complexation of uranyl ions ${ }^{4-6}$ with oxygen-based complexes consisting of highvalent elements such as $\mathrm{S}, \mathrm{Cr}$, Se, Mo or W have high relevance for nuclear waste disposal, owing to their use in nuclear engineering (e.g., $\mathrm{Mo}^{7}$ and $\mathrm{W}^{8}$ are used in refractory alloys) or due to their formation in burn-up processes of nuclear fuel (Mo, Se). ${ }^{9}$ Actinide sulfates, chromates and selenates are known to form diverse and complex structures with such interesting structural features as cation-cation interactions, microporous frameworks and nanotubules. ${ }^{10-16}$ Actinide molybdates and tungstates may adopt structure types more resembling dense complex oxides than oxosalts. ${ }^{4}$ In comparison to molybdates, uranyl tungstates are less studied with relatively few reports available in the

${ }^{a}$ Lobachevsky State University of Nizhny Novgorod, Gagarin Av. 23b, 603950 Nizhny Novgorod, Russia

${ }^{b}$ Anorganische Chemie II, Department Chemie und Pharmazie, Friedrich-Alexander-Universität Erlangen-Nürnberg, Egerlandstr. 1, D-91058 Erlangen, Germany

${ }^{c}$ Institute of Energy and Climate Research (IEK-6), Forschungszentrum Jülich, D-52428Jülich, Germany.E-mail: e.alekseev@fz-juelich.de; Fax: +492461612450

${ }^{d}$ Institut für Geowissenschaften, Kiel University, Ludewig-Meyn-Str. 10, D-24118 Kiel, Germany

${ }^{e}$ Department of Crystallography, Saint Petersburg State University, Dekabristov 16, 199155 Sankt Petersburg, Russia

${ }^{f}$ Institut für Kristallographie, RWTH Aachen University, Jägerstraße 17-19, D-52066 Aachen, Germany

$\dagger$ Electronic supplementary information (ESI) available: Includes powder diffractograms and IR spectra. CCDC 881326-881328. For ESI and crystallographic data in CIF or other electronic format see DOI: $10.1039 / \mathrm{c} 2 \mathrm{dt} 31000 \mathrm{~g}$ literature. ${ }^{17-23}$ The known $\mathrm{Cs}$ and $\mathrm{Rb}$ uranyl tungstates adopt $1 \mathrm{D}$ or $2 \mathrm{D}$ structures with $\mathrm{WO}_{4}$ or $\mathrm{WO}_{5}$ monomers and $\mathrm{W}_{2} \mathrm{O}_{8}$ dimers. ${ }^{18,21,22,24,25}$ Here we report on the synthesis and structures of three new uranyl tungstate phases possessing novel structure types: $\alpha-/ \beta-\mathrm{Cs}_{2}\left[\left(\mathrm{UO}_{2}\right)_{2}\left(\mathrm{~W}_{2} \mathrm{O}_{9}\right)\right]$ (1 and $\mathbf{2}$ respectively) and $\mathrm{Rb}_{6}\left[\left(\mathrm{UO}_{2}\right)_{7}\left(\mathrm{WO}_{5}\right)_{2}\left(\mathrm{~W}_{3} \mathrm{O}_{13}\right) \mathrm{O}_{2}\right](3)$.

The compounds studied in this work were obtained by hightemperature solid state reactions from mixtures of $\mathrm{UO}_{3}, \mathrm{WO}_{3}$, and $\mathrm{RbNO}_{3}$, or $\mathrm{CsNO}_{3}$. Single crystals of $\mathbf{1}$ and $\mathbf{2}$ were obtained as follows. + First, a $\mathrm{Cs}-\mathrm{W}$ bronze with $\mathrm{Cs}_{2} \mathrm{~W}_{2} \mathrm{O}_{7}$ composition ${ }^{26}$ was obtained by heating a mixture of $\mathrm{CsNO}_{3}(0.500 \mathrm{~g}$, $2.57 \mathrm{mmol})$ and $\mathrm{WO}_{3}(0.595 \mathrm{~g}, 2.57 \mathrm{mmol})$ at $450{ }^{\circ} \mathrm{C}$ and $500{ }^{\circ} \mathrm{C}$ for $24 \mathrm{~h}$ in porcelain crucibles. The obtained $\mathrm{Cs}_{2} \mathrm{~W}_{2} \mathrm{O}_{7}$ $(0.626 \mathrm{~g}, 0.84 \mathrm{mmol})$ phase was mixed with $\mathrm{UO}_{3}(0.200 \mathrm{~g}$, $0.70 \mathrm{mmol})$ to observe the ratio of $\mathrm{Cs}: \mathrm{U}: \mathrm{W}=1.2: 1: 1.2$. The mixture was heated to $820^{\circ} \mathrm{C}$ for $4 \mathrm{~h}$ and cooled down to room temperature with the rate of $7{ }^{\circ} \mathrm{C} \mathrm{h}^{-1}$. The obtained product consisted of yellowish crystals of $\mathbf{1}$ and $\mathbf{2}$ immersed within an amorphous yellow solid. Powder samples consisting of both 1 and 2 phases were prepared by heating a mixture of $\mathrm{CsNO}_{3}(0.273 \mathrm{~g}, 1.40 \mathrm{mmol}), \mathrm{UO}_{3}(0.400 \mathrm{~g}, 1.40 \mathrm{mmol})$ and $\mathrm{WO}_{3}(0.324 \mathrm{~g}, 1.40 \mathrm{mmol})$ in a $1: 1: 1$ molar ratio at $750{ }^{\circ} \mathrm{C}$ for $72 \mathrm{~h}$ in a porcelain crucible. X-ray powder diffraction indicated that the sample is a mixture of $\alpha$ - and $\beta-\mathrm{Cs}_{2}\left[\left(\mathrm{UO}_{2}\right)_{2}\left(\mathrm{~W}_{2} \mathrm{O}_{9}\right)\right]$ in a ratio $1: 4$ (Fig. $\mathrm{S} 1 \dagger$ ). Our attempts to obtain pure powders of either $\alpha$ - or $\beta-\mathrm{Cs}_{2}\left[\left(\mathrm{UO}_{2}\right)_{2}\left(\mathrm{~W}_{2} \mathrm{O}_{9}\right)\right]$ were not successful. Single crystals of 3 were obtained by high-temperature solid-state reaction of an initial mixture of $\mathrm{RbNO}_{3}(0.103 \mathrm{~g}, 0.70 \mathrm{mmol}), \mathrm{UO}_{3}$ $(0.200 \mathrm{~g}, 0.70 \mathrm{mmol})$ and $\mathrm{WO}_{3}(0.162 \mathrm{~g}, 0.70 \mathrm{mmol})$ with a $\mathrm{Rb}: \mathrm{U}: \mathrm{W}$ ratio equal to $1: 1: 1$. The mixture was slowly heated to $870{ }^{\circ} \mathrm{C}$ in a porcelain crucible and then cooled down to $400{ }^{\circ} \mathrm{C}$ at a rate of $4{ }^{\circ} \mathrm{C} \mathrm{h}^{-1}$. The product consisted of yellowish crystals of $\mathbf{3}$ in a glassy amorphous mass. Single crystals of the obtained phases were investigated by means of single-crystal $\mathrm{X}$-ray diffraction analysis. It is noteworthy that the crystals of $\mathbf{1}$ were observed to be of considerably lower quality in comparison to the crystals of $\mathbf{2}$, which may indicate its lower stability.

The structures of all three compounds are based upon 2D uranyl tungstate layers (Fig. 1). The layers in these structures are based on $\mathrm{UO}_{2}{ }^{2+}$ linear groups linked with oxo-tungstates polyhedra. In all three structures, $\mathrm{U}^{6+}$ cations form linear uranyl groups, $[\mathrm{O}=\mathrm{U}=\mathrm{O}]^{2+}$, equatorially coordinated by five $\mathrm{O}$ atoms. In the structures of $\mathbf{1}$ and $2, \mathrm{UO}_{7}$ pentagonal bipyramids share edges to 


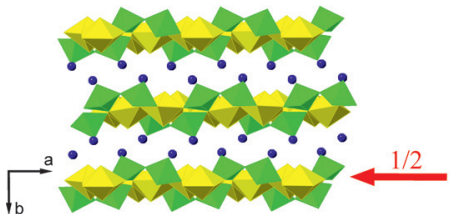

(a)

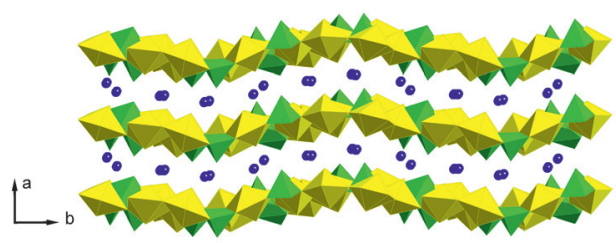

(c)

Fig. 1 Fragments of $\mathbf{1}$ (a), 2 (b) and $\mathbf{3}$ (c) crystal structures. Uranium polyhedra are shown in yellow, tungsten in green and alkali atoms in dark violet. The red arrow indicates the shift of adjacent layers on going from 2 to 1.

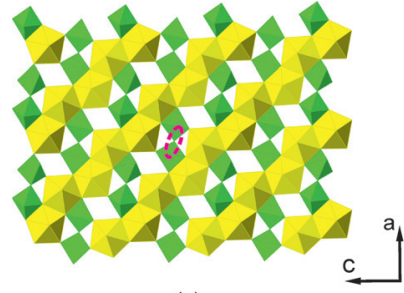

(a)

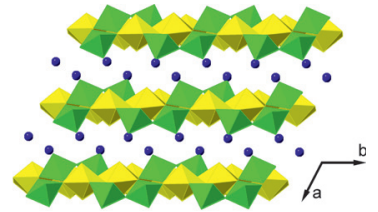

(b)

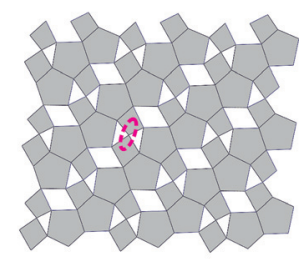

(b)

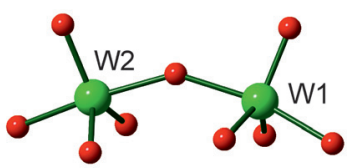

(c)

Fig. 2 The fragments of 2D uranium-oxotungstates layers in $\mathbf{1}$ and 2 (a, on the example of $\left.\beta-\mathrm{Cs}_{2}\left[\left(\mathrm{UO}_{2}\right)_{2}\left(\mathrm{~W}_{2} \mathrm{O}_{9}\right)\right]\right)$ with their anion topologies (b) and the structure of $\mathrm{W}_{2} \mathrm{O}_{9}$ dimers within these layers (c). Uranium polyhedra are shown in yellow, tungsten in green, oxygen atoms in red.

form infinite chains linked by the $\mathrm{W}_{2} \mathrm{O}_{9}$ dimers consisting of two corner-sharing $\mathrm{WO}_{5}$ distorted trigonal bipyramids (Fig. 2). The $\mathrm{W}^{6+}$ coordination is quite noteworthy as it contains welldefined $\mathrm{WO}_{2}{ }^{2+}$ dioxo-groups ('tungstyl' cations) with the $\mathrm{W}-\mathrm{O}$ bond lengths ranging from $1.723(6) \AA$ to $1.79(1) \AA$. The $\mathrm{WO}_{2}{ }^{2+}$ groups have a bent configuration with the $\mathrm{O}-\mathrm{W}-\mathrm{O}$ angles close to $113^{\circ}$. The other three bonds in the $\mathrm{WO}_{5}$ polyhedra are significantly longer [1.88(1) $\AA-1.95(1) \AA]$. The angles in WO5 trigonal bipyramids are significantly differ from angles in tetragonal pyramidal configuration (for example $\mathrm{W}_{10}$ in 3). The axial $\mathrm{O}-\mathrm{W}-\mathrm{O}$ angles in trigonal bipyramids are $165^{\circ}-168^{\circ}$. Similar angles in tetragonal pyramid are $\sim 150^{\circ}$. The angles in $\mathrm{WO}_{5}$ trigonal bipyramids within the plane perpendicular to the axial bonds are quite close to the ideal $120^{\circ}\left[112^{\circ}-129^{\circ}\right]$. In contrast, same angles in the tetragonal pyramidal configuration are from $104^{\circ}$ to $140^{\circ}$.

The $\mathrm{W}_{2} \mathrm{O}_{9}$ dimers are located between the chains of uranyl polyhedra, providing their linkage into dense 2D layers. We note

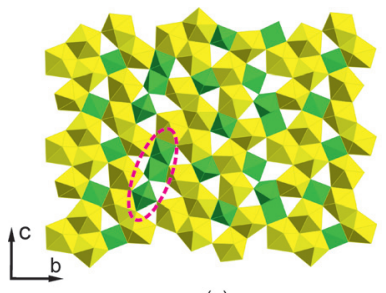

(a)

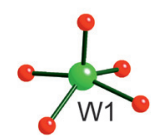

(c)

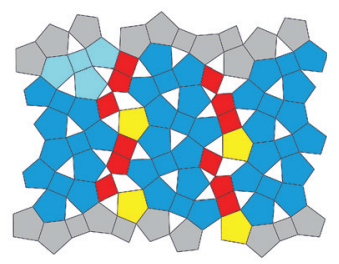

(b)

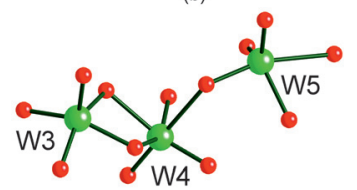

(d)
Fig. 3 A fragment of the 2D uranyl-oxotungstate layers in 3 (a) with its anion topology (b, see text for details) and the coordination of the $\mathrm{WO}_{5}$ and $\mathrm{W}_{3} \mathrm{O}_{13}$ groups (c, d). Uranium polyhedra are shown in yellow, tungsten in green, oxygen atoms in red.

that tungstate dimers have previously been observed in uranyl phases. However, in all reported structures, ${ }^{10,18,25}$ they are based upon edge-sharing fivefold polyhedra and therefore have the $\mathrm{W}_{2} \mathrm{O}_{8}$ composition. The structures of $\mathbf{1}$ and $\mathbf{2}$ are the first examples of uranyl phases containing dimers of corner-sharing fivefold coordination polyhedra of high-valent cations.

The topology of the interpolyhedral linkage in $\mathbf{1}$ and $\mathbf{2}$ can be described using the anion-topology approach (Fig. 2b). ${ }^{27}$ The observed topology is novel and has not been detected previously in any other inorganic compound. However, it is closely related to the uranophane-type topology and can be obtained from the latter by insertion of an additional $\mathrm{O}$ atom, which is the bridging oxygen atom in the $\mathrm{W}_{2} \mathrm{O}_{9}$ dimer (shown in Fig. $2 \mathrm{a}$ and $\mathrm{b}$ by red dashed ellipses). ${ }^{28-30}$

The uranyl tungstate layers in $\mathbf{1}$ and $\mathbf{2}$ are linked by $\mathrm{Cs}^{+}$cations located in the interlayer space. The two modifications differ from each other by the layer stacking mode and can be considered as polytypes. The unit-cell parameters within the layer are almost identical $\left[a \times c=9.6228 \times 10.2275 \AA^{2}\left(\beta \sim 90^{\circ}\right)\right.$ for 1 and $b \times c$ $=9.6148 \times 10.2371 \AA^{2}\left(\alpha \sim 90^{\circ}\right)$ for 2], whereas the parameters along the stacking of the layers are different $[b=14.3597(5)$ for 1 and $a=7.6582(7) \AA$ for 2]. The unit cells in $\mathbf{1}$ and $\mathbf{2}$ contain two and one layers, respectively, which allows to identify the structures of the $\alpha$ - and $\beta$-phases as $-2 M$ and $-1 A$ polytypes of $\mathrm{Cs}_{2}\left[\left(\mathrm{UO}_{2}\right)_{2}\left(\mathrm{~W}_{2} \mathrm{O}_{9}\right)\right]$, respectively. ${ }^{31}$ The relationship between 2 and $\mathbf{1}$ is indicated by a red arrow in Fig. 1. It is of interest that, despite the layered character of most uranyl oxo-compounds, polytypism is not a common phenomenon in this class of structures. The only previously known example of polytypism in uranylbased materials is that of $\alpha$ - and $\beta-\mathrm{Ag}_{2}\left[\left(\mathrm{UO}_{2}\right) \mathrm{W}_{2} \mathrm{O}_{8}\right],{ }^{17}$ which have been considered as $\mathrm{Ag}_{2}\left[\left(\mathrm{UO}_{2}\right) \mathrm{W}_{2} \mathrm{O}_{8}\right]-2 M$ and $\mathrm{Ag}_{2}\left[\left(\mathrm{UO}_{2}\right)\right.$ $\left.\mathrm{W}_{2} \mathrm{O}_{8}\right]-2 \mathrm{O}$ polytypes, respectively.

The crystal structure of $\mathrm{Rb}_{6}\left[\left(\mathrm{UO}_{2}\right)_{7}\left(\mathrm{WO}_{5}\right)_{2}\left(\mathrm{~W}_{3} \mathrm{O}_{13}\right) \mathrm{O}_{2}\right](3)$ is more complicated than those of $\mathbf{1}$ and $\mathbf{2}$. It is based on 2D corrugated layers parallel to (100) (Fig. 1c), consisting of $\mathrm{UO}_{7}, \mathrm{WO}_{5}$ and $\mathrm{W}_{3} \mathrm{O}_{13}$ groups (Fig. 3a). There are seven independent $\mathrm{U}$ sites in 3. However, all sites adopt pentagonal bipyramidal $\mathrm{UO}_{7}$ configurations, which display larger distortions compared to $\mathbf{1}$ and 2. The uranyl $\mathrm{U}=\mathrm{O}$ bond lengths vary from $1.70(2) \AA$ to $1.86(2) \AA$, whereas the equatorial U-O bond lengths are in the 
range of 2.16(2)-2.64(1) $\AA$. The $\mathrm{UO}_{7}$ pentagonal bipyramids share edges to form trimers and tetramers (Fig. 3a).

The coordination of the $\mathrm{W}$ sites in $\mathbf{3}$ is quite remarkable. The W1, W2, W3 and W5 sites have square pyramidal coordination. The apical $\mathrm{W}=\mathrm{O}$ bonds are rather short $[1.67-1.72 \AA]$, whereas equatorial $\mathrm{W}-\mathrm{O}$ bonds are much longer $[1.88-2.00 \AA]$. The coordination geometry of the W4 site can be described as strongly distorted octahedral. Within the $\mathrm{W}_{4} \mathrm{O}_{6}$ polyhedron, there is one short $[1.64(2) \AA]$, four intermediate [1.83(2)-2.14(2) $\AA]$, and one long [2.35(2) $\AA$ ] bond. This type of coordination can be described as $[1+4+1]$ and is quite typical for $\mathrm{W}^{6+}$ atoms in uranyl oxocompounds. ${ }^{17,24}$ The $\mathrm{W}^{1} \mathrm{O}_{5}$ and $\mathrm{W} 2 \mathrm{O}_{5}$ pyramids are isolated from other $\mathrm{W}$ polyhedra and are linked exclusively to $\mathrm{UO}_{7}$ bipyramids. In contrast, the $\mathrm{W}_{3} \mathrm{O}_{5}$ square pyramid and the $\mathrm{W}_{4} \mathrm{O}_{6}$ octahedron share an edge to form a $\mathrm{W}_{2} \mathrm{O}_{8}$ dimer, which is further linked to the $\mathrm{W}_{5} \mathrm{O}_{5}$ pyramid through corner linkage (Fig. 3d). The resulting $\mathrm{W}_{3} \mathrm{O}_{13}$ complex is rather unique and has not been observed previously in any non-molecular inorganic phase. However, $\mathrm{W}_{3} \mathrm{O}_{13}$ groups have been described in some Keggin-type tungstate clusters ${ }^{32}$ and mixed-valence compounds, ${ }^{33}$ but have different geometry.

The trimers and tetramers of uranyl polyhedra along with the $\mathrm{W}$ polyhedra share edges to form $\left[\left(\mathrm{UO}_{2}\right)_{7}\left(\mathrm{WO}_{5}\right)_{2}\left(\mathrm{~W}_{3} \mathrm{O}_{13}\right) \mathrm{O}_{2}\right]$ complex layers, which are new to the structural chemistry of inorganic compounds.

The described diversity of the various building units within the $\left[\left(\mathrm{UO}_{2}\right)_{7}\left(\mathrm{WO}_{5}\right)_{2}\left(\mathrm{~W}_{3} \mathrm{O}_{13}\right) \mathrm{O}_{2}\right]_{2 \infty}{ }^{-}$layers generates the topological complexity of the sheets. For a description of the topological features of $\mathbf{3}$ we employ a similar approach used for the analysis of the topology in $\mathbf{1}$ and $\mathbf{2}$. For the sake of clarity, the tiling fragments are coloured in order to emphasize their packing modes (Fig. 3b). The four membered "blue fragments" (one of which is shown in light blue to catch its form) are forming 1D chains, parallel to $c$. The "blue fragments" point in opposite directions in neighbouring chains. The "blue" group and geometrically similar ones play an important role in the topology of uranyl tungstates. ${ }^{18-22,34-36}$ The "blue" chains are linked by intermediate "red" and "yellow" groups which are the projections of $\mathrm{W}_{3} \mathrm{O}_{13}$ and single $\mathrm{UO}_{7}$ units, respectively. To the best of our knowledge, this is the first time that such a topology has been found in inorganic oxo-salt compounds.

\section{Acknowledgements}

We are grateful for support provided by Deutsche Forschungsgemeinschaft (DFG) within the DE 412/43-1 research project and by Helmholtz Association for the support within VH-NG-815 project. SVK was supported in this study by an internal grant of St. Petersburg State University [3.37.84.2011].

\section{Notes and references}

Crystallographic data for 1 : yellow plate, monoclinic, $M_{\mathrm{r}}=1317.58$, $P 2_{1} / n, Z=4, a=9.6228(3) \AA, b=14.3597(5) \AA, c=10.2275(4) \AA, \beta=$ $90.686(3)^{\circ}, V=1413.14(9) \AA^{3}(T=293(2) \mathrm{K}), \mu=442.09 \mathrm{~cm}^{-1}, N_{\mathrm{Ref}}=$ $19060 / 2655, R_{\text {int }}=0.0669, R_{1}=0.0745$ for $F_{\mathrm{o}}{ }^{2}>2 \sigma\left(F_{\mathrm{o}}{ }^{2}\right), \mathrm{w} R_{2}=$ 0.1966 for all data. Crystallographic data for 2: yellow plate, triclinic, $M_{\mathrm{r}}$ $=1317.58, P \overline{1}, Z=2, a=7.6582(7) \AA, b=9.6148(7) \AA, c=10.2371(5)$ $\AA, \alpha=90.610(5)^{\circ}, \beta=94.765(6)^{\circ}, \gamma=109.300(8)^{\circ}, V=708.38(9) \AA^{3}$ $(T=293(2) \mathrm{K}), \mu=442.09 \mathrm{~cm}^{-1}, N_{\text {Ref }}=5146 / 2801, R_{\text {int }}=0.0358, R_{1}=$ 0.0323 for $F_{\mathrm{o}}{ }^{2}>2 \sigma\left(F_{\mathrm{o}}{ }^{2}\right), \mathrm{w} R_{2}=0.0662$ for all data. Crystallographic data for 3: yellow plate, monoclinic, $M_{\mathrm{r}}=3722.28, P 2_{1}, Z=2$, $a=7.04192(13) \AA, b=26.8465(3) \AA, c=10.66563(15) \AA, \beta=$ 103.6755(16) ${ }^{\circ}, V=1959.18(5) \AA^{3}(T=293(2) \mathrm{K}), \mu=509.36 \mathrm{~cm}^{-1}$, $N_{\text {Ref }}=26586 / 6832, R_{\text {int }}=0.0738, R_{1}=0.0481$ for $F_{\mathrm{o}}{ }^{2}>2 \sigma\left(F_{\mathrm{o}}{ }^{2}\right)$, $\mathrm{w} R_{2}=0.1018$ for all data.

1 R. C. Ewing, Proc. Natl. Acad. Sci. U. S. A., 1999, 96, 3432-3439.

2 L. N. Oji, W. R. Wilmarth and D. T. Hobbs, Nucl. Technol., 2010, 169, 143-149.

3 A. P. Deditius, S. Utsunomiya and R. C. Ewing, J. Alloys Compd., 2007, 444-445, 584-589.

4 P. C. Burns, in Structural Chemistry of Inorganic Actinide Compounds, ed. S. V. Krivovichev, P. C. Burns and I. G. Tananaev, Elsevier, Amsterdam, 2007, pp. 1-30.

5 R. J. Silva and H. Nitsche, Radiochim. Acta, 1995, 70-1, 377-396.

6 R. J. M. Konings, O. Beneš and J. C. Griveau, in Comprehensive Nuclear Materials, ed. J. M. K. Rudy, Editor-in-Chief, Elsevier, Oxford, 2012, pp. 1-20.

7 D. G. Cacuci, Handbook of Nuclear Engineering Vol. 2, Reactor Design, Springer, New York, 2010.

8 J. A. Webb and I. Charit, Nucl. Eng. Des., 2011, 241, 2968-2973.

9 C. Frechou, S. Aguerre, J.-P. Degros, G. Kerlau and T. Grangeon, Talanta, 2007, 72, 1166-1171.

10 S. V. Krivovichev and P. C. Burns, in Structural Chemistry of Inorganic Actinide Compounds, ed. S. V. Krivovichev, P. C. Burns and I. G. Tananaev, Elsevier, Amsterdam, 2007, pp. 95-182.

11 D. K. Unruh, M. Baranay, L. Pressprich, M. Stoffer and P. C. Burns, J. Solid State Chem., 2012, 186, 158-164.

12 V. M. Kovrugin, V. V. Gurzhiy, S. V. Krivovichev, I. G. Tananaev and B. F. Myasoedov, Mendeleev Commun., 2012, 22, 11-12.

13 S. V. Krivovichev, V. Kahlenberg, R. Kaindl, E. Mersdorf, I. G. Tananaev and B. F. Myasoedov, Angew. Chem., Int. Ed., 2005, 44, 1134-1136.

14 S. V. Krivovichev, V. Kahlenberg, I. G. Tananaev, R. Kaindl, E. Mersdorf and B. F. Myasoedov, J. Am. Chem. Soc., 2005, 127, 1072-1073.

15 E. V. Alekseev, S. V. Krivovichev and W. Depmeier, Angew. Chem., Int. Ed., 2008, 47, 549-551.

16 S. V. Krivovichev, Eur. J. Inorg. Chem., 2010, 2594-2603.

17 S. V. Krivovichev and P. C. Burns, Solid State Sci., 2003, 5, 373-381.

18 S. Obbade, C. Dion, E. Bekaert, S. Yagoubi, M. Saadi and F. Abraham, J. Solid State Chem., 2003, 172, 305-318.

19 S. Obbade, S. Yagoubi, C. Dion, M. Saadi and F. Abraham, J. Solid State Chem., 2004, 177, 1681-1694.

20 R. E. Sykora and T. E. Albrecht-Schmitt, J. Solid State Chem., 2004, 177, 3729-3734.

21 E. V. Alekseev, S. V. Krivovichev, W. Depmeier, T. Armbruster, H. Katzke, E. V. Suleimanov and E. V. Chuprunov, J. Solid State Chem., 2006, 179, 2977-2987.

22 S. Yagoubi, S. Obbade, M. Benseghir, F. Abraham and M. Saadi, Solid State Sci., 2007, 9, 933-943.

23 E. V. Alekseev, S. V. Krivovichev and W. Depmeier, J. Solid State Chem., 2009, 182, 2977-2984.

24 E. V. Alekseev, S. V. Krivovichev, W. Depmeier, O. I. Siidra, K. Knorr, E. V. Suleimanov and E. V. Chuprunov, Angew. Chem., 2006, 118, 7391-7393.

25 S. V. Krivovichev and P. C. Burns, Solid State Sci., 2003, 5, 373-381.

26 I. Brüdgam, J. Fuchs, H. Hartl and R. Palm, Angew. Chem., Int. Ed., 1998, 37, 2668-2671.

27 Y. A. Zakutkin and V. A. Blatov, J. Struct. Chem., 2001, 42, 436-445.

28 S. V. Krivovichev and P. C. Burns, Can. Mineral., 2000, 38, 717-726.

29 S. V. Krivovichev, Structural Crystallography of Inorganic Oxysalts, Oxford University Press, Oxford, New York, 2009.

30 S. Obbade, S. Yagoubi, C. Dion, M. Saadi and F. Abraham, J. Solid State Chem., 2004, 177, 1681-1694.

31 A. Guinier, G. B. Bokij, K. Boll-Dornberger, J. M. Cowley, S. Durovič, H. Jagodzinski, P. Krishna, P. M. d. Wolff, B. B. Zvyagin, D. E. Cox, P. Goodman, T. Hahn, K. Kuchitsu and S. C. Abrahams, Acta Crystallogr., Sect. A: Found. Crystallogr., 1984, 40, 399-404.

32 J.-Y. Niu, Z.-L. Wang and J.-P. Wang, J. Solid State Chem., 2004, 177, $3411-3417$.

33 C. G. Young, Coord. Chem. Rev., 1989, 96, 98-251.

34 E. V. Alekseev, S. V. Krivovichev, W. Depmeier, T. Malcherek, E. V. Suleimanov and E. V. Chuprunov, Z. Kristallogr., 2007, 222, 391-395.

35 S. V. Krivovichev and P. C. Burns, J. Solid State Chem., 2002, 168, 245-258.

36 S. V. Krivovichev and P. C. Burns, Solid State Sci., 2003, 5, 481-485. 